\title{
Structural, Magnetic, and X-Band Microwave Absorbing Properties of Ni-Ferrites Prepared Using Oxidized Mill Scales
}

\author{
Ardita Septiani *, Novrita Idayanti, Tony Kristiantoro, Dedi, Nadya Larasati \\ Kartika, Dadang Mulyadi, Asep Rusmana, Pepen Sumpena
}

\author{
Research Center for Electronics and Telecommunication \\ Indonesian Institute of Sciences \\ Jl. Sangkuriang 154 D - Kampus LIPI, Gedung 20, Lt. 4 \\ Bandung, Indonesia
}

\begin{abstract}
This study aims to evaluate the structural, magnetic, and microwave absorbing properties at the X-band region of oxidized mill scales as by-product derived from a steel making process by means of a facile solid-state reaction. The oxidized mill scales were heated at $600{ }^{\circ} \mathrm{C}$ for $4 \mathrm{~h}$ followed by mixing with NiO. A calcination process took place at $900{ }^{\circ} \mathrm{C}$ and sintering process were conducted at $1260{ }^{\circ} \mathrm{C}$ with a milling process conducted in between the heating process. X-ray diffraction (XRD) and scanning electron microscope (SEM) equipped with energy dispersive spectrometer (EDS) were employed to evaluate the structural properties of the Ni-ferrites samples. Remacomp measurement were conducted to evaluate the magnetic properties and vector network analyzer (VNA) to measure its microwave properties. A single phase of $\mathrm{NiFe}_{2} \mathrm{O}_{4}$ was confirmed by XRD data. The site occupancies derived from the Rietveld refinement shows that the Ni:Fe:O ratio deviates from the 1:2:4 ratio as that suggests vacancies formed in the $\mathrm{Ni}^{2+}$ and $\mathrm{Fe}^{3+}$ that lowers the unit cell density to $5.08 \mathrm{~g} / \mathrm{cm}^{3}$ that further confirmed by EDS measurement. The coercivity of $11 \mathrm{kOe}$ is also higher than the bulk $\mathrm{NiFe}_{2} \mathrm{O}_{4}$ prepared by the chemical grade raw materials. The reflection data of the microwave properties at X-band of 8-12 GHz do not shows significant absorptions. This study suggests that the selected preparation method yields a single phase, however with the significant crystallographic defects and has less 'soft' magnetic properties compared to $\mathrm{NiFe}_{2} \mathrm{O}_{4}$ prepared using chemical grade by previous study.
\end{abstract}

Keywords: Spinel ferrites, mill scales, soft magnets, magnetic materials

\section{INTRODUCTION}

The iron and steel making industry are estimated to generate more than ten million tons of scales every year globally [1]. The scales have ranging levels of oxidation depending on the type of the milling process it derives from. Recovery of such scales are usually includes the re-melting and reduction process, which are energyexhaustive [1]-[2], even more so for scales that are derived from milling process at elevated temperatures. The scales from this process have higher oxidation states, therefore, to yield the metal form, it requires similar amount energy to the extraction from its raw mineral. The high content of the iron in the scales allows it to be considered secondary raw materials. The greener alternative is to utilize the scales to produce material in the ferrites form.

Compared to steel and irons that are dominantly utilized as structural materials, ferrites have the application in the electrical and electronics that partly owing to their particular permittivity and permeability values. Several studies attempted to utilize mill scales to produce ferrites such as $\mathrm{Zn}$-ferrites [3], Ba-hexaferrites

\footnotetext{
* Corresponding Author.

Email: ardi012@lipi.go.id

Received: November 15, 2020 ; Revised: February 21, 2021

Accepted: March 15, 2021 ; Published: August 31, 2021

Open access under CC-BY-NC-SA

(C) 2021 PPET - LIPI
}

[3]-[4], Mg-ferrites [5], and NiZn-ferrites [6]. Niferrites has considerably lower magnetic crystalline anisotropy constant of $0.07 \times 10^{6} \mathrm{erg} / \mathrm{cm}^{3}$ [7] in comparison to other ferrites, such as, NiZn-ferrites at $2.63 \times 10^{5}$ to $5.94 \times 10^{5} \mathrm{erg} / \mathrm{cm}^{3}$ [8], Co-ferrites at 2.96 $\times 10^{6} \mathrm{erg} / \mathrm{cm}^{3}$ [7] and Mg-ferrites $6.1 \times 10^{6} \mathrm{erg} / \mathrm{cm}^{3}$ [9]. Lower values of the magnetocrystalline anisotropy is associated with lower loss of energy for each magnetization and demagnetization cycle, thus suitable to be classified as a soft magnetic material. $\mathrm{NiFe}_{2} \mathrm{O}_{4}$ as ferrimagnetic materials are closely related with the resonance behaviour, which is strongly associated to magnetic materials. Ferromagnetic resonance, electron paramagnetic resonance, among others, are few phenomenons occur at varying frequencies [10], which compose the resonance behaviour of materials. X-band $(8-12 \mathrm{GHz})$ is widely used in terrestrial wireless communication. Combined with its low electrical conductivity that results in preventing eddy currents and its high permeability, ferrites can be used in telecommunication application in both resonance and non-resonance states. Significant resonance effect in Xband results in the possibility of utilizing Ni-ferrites prepared using mill scale as electromagnetic shielding by absorbing the incoming electromagnetic waves, whereas the non-existence of resonance behaviour in $\mathrm{Ni}$-ferrites makes it potential to use as circulators.

In the previous study, we have tried to prepare the hexagonal barium ferrites using the mill scale with the 
aid of roasting process to obtain $\mathrm{Fe}_{2} \mathrm{O}_{3}$ [4]. In this study, we aim to prepare $\mathrm{Ni}$-ferrites from the oxidized mill scales. It belongs to soft magnets class that exhibits low coercivity. Ni-ferrites belongs to spinel ferrites with general structure of $\mathrm{AB}_{2} \mathrm{X}_{4}$ that in this case is in the form of $\mathrm{NiFe}_{2} \mathrm{O}_{4}$. Compared to spinel ferrites $\mathrm{Fe}_{3} \mathrm{O}_{4}$, the arrangement of the atoms of $\mathrm{NiFe}_{2} \mathrm{O}_{4}$ differs due to some inversion, with a more accurate notation of $\left[\mathrm{Ni}_{1-\mathrm{x}} \mathrm{Fe}_{\mathrm{x}}\right]\left[\mathrm{Ni}_{\mathrm{x}} \mathrm{Fe}_{2-\mathrm{x}}\right] \mathrm{O}_{4}$. The antiparallel pairings of $\mathrm{Fe}^{3+}$ at different sites contribute to the collinear magnetic ordering with the Curie temperature of $870 \mathrm{~K}$ [11]. $\mathrm{NiFe}_{2} \mathrm{O}_{4}$ has chemical stability at elevated temperature, adequate mechanical strength, and also offers moderate magnetic properties that makes $\mathrm{NiFe}_{2} \mathrm{O}_{4}$ suitable in magnetic recording media, magnetic refrigeration, levitated railways systems, and also as chemical catalyst.

In the making of $\mathrm{Ni}$-ferrites from analytic grade materials, various preparation methods have been employed in past studies, e.g., thermal decomposition [12], solid-state [13], co-precipitation [14], hydrothermal [15], and sol-gel [16]. Compared to these methods, solid-state offers a direct and high yield product that are significantly easier to scale up compared to other methods. This method also produces relatively lower chemical wastes during the synthesis process, also, require less catalytic chemical that may remain in the final product. The setback of this method is the use of elevated temperature above $1000{ }^{\circ} \mathrm{C}$.

The utilization of the mill scales as the starting materials for the ferrite groups from the past studies have been laid out. To the best of our knowledge, the fabrication of Ni-ferrites using mill scales has not been found yet. In fact, in comparison to the studies within the vast ferrites group that are made using the analytic grade raw materials, the studies of the utilization of mill scale in ferrite making is still in its infancy. Furthermore, it is interesting to explore the potential usage of mill scale using the direct and facile solid-state method, evaluate its soft magnetic characteristics, as well as their response to the electromagnetic field.

Therefore, this paper aims to prepare $\mathrm{Ni}$-ferrites using a facile solid-state method, utilizing mill scales that are considered as by-product or industrial waste, with the aid of oxidation process as the pre-treatment of the mill scales. The chemical and structural properties including the microstructure, the crystal structure, and elemental composition of Ni-ferrite prepared using the oxidized mill scales will be set forth. Its remanence, and the coercivity, as the parameters that well-suited to evaluate its magnetic "softness", will also be presented in this study. Lastly, the reflection loss of Ni-ferrites prepared using mill scales, that represent its electromagnetic response in X-band region will also be provided.

\section{MATERIALS AND MethodS}

\section{A. Materials and Synthesis}

The oxidized mill scale was obtained from the hot strip mill in steel making process. The Fe-rich oxidized mill scales were first washed using demineralized water then crushed and ground into a powder form. Milling for $50 \mathrm{~h}$ in a jar mill helped breaks down most of the scales with subsequent screening using a $45 \mu \mathrm{m}$ opening mesh. Roasting at $600{ }^{\circ} \mathrm{C}$ for $4 \mathrm{~h}$ was conducted to aid the formation of $\mathrm{Fe}^{3+}$ ions by first increasing the amount of hematite (rhombohedral $\mathrm{Fe}_{2} \mathrm{O}_{3}$ ) as our previous study suggests [4]. Mixing with $\mathrm{NiO}$ powders (technical grade, Anhui Fitech Materials) were conducted in a high energy shaker mill for $10 \mathrm{~h}$. Calcination were brought at $900^{\circ} \mathrm{C}$ for $4 \mathrm{~h}$. The resulting powders then further milled in the shaker mill for $5 \mathrm{~h}$ with the addition of polyvinyl alcohol (Merck) that acts as a binder for the sintering process. The powders were compacted into ring-shaped pellets with dimension of outer diameter $8.2 \pm 0.1 \mathrm{~mm}$, inner diameter of $3.9 \pm 0.1 \mathrm{~mm}$, and height of $3.8 \pm 0.2$ $\mathrm{mm}$ compacted at $5.9 \mathrm{ton} / \mathrm{cm}^{2}, 8.4 \mathrm{ton} / \mathrm{cm}^{2}$, and 10.9 ton $/ \mathrm{cm}^{2}$. The variations for the compaction pressures were selected at relatively high pressure to encourage the densification of the powders. The sintering process was conducted at $1260{ }^{\circ} \mathrm{C}$ for $3 \mathrm{~h}$.

\section{B. Characterization}

X-ray fluorescence (XRF, Bruker, S2PUMA) of the mill scale were carried out to reveal the elemental composition of the mill scale as the raw materials. Structural investigation was first performed by X-ray diffraction (XRD, Bruker D8 Advance) measurement using $\mathrm{Cu}-\mathrm{k} \alpha$ radiation to determine the phase formation, further analyzed using Rietveld refinements with Fullprof program [17]. A scanning electron microscope (SEM, JEOL JSM-IT300LV) that was equipped with Xray spectroscopy (EDS) was used to provide the microstructure profile and analyze the distribution of the elemental composition. Mass density was measured with Archimedes method using a Mettler Toledo, ML204T.

Magnetic hysteresis was obtained using a Remacomp (Magnet-Physik) that offers high resolution in the lower field and is useful for measuring the coercivity for soft magnets. For this study, samples in the form of ring with varying compaction pressure were measured at a frequency of $800 \mathrm{~Hz}$ and amplitude of $0.95 \mathrm{~V}$.

The reflection loss was measured using a vector network analyzer (VNA, Anritsu MS46322A) with the cavity for measuring in the X-band region of 8-12 GHz. For this measurement, the powdered sample was placed in an acrylic die of dimension $25 \mathrm{~mm} \times 15 \mathrm{~mm} \times 2 \mathrm{~mm}$.

\section{RESULT AND DISCUSSION}

Table 1 shows the elemental composition of the mill scales that was used as the starting materials. Other than Fe with a fraction of 96.913 ar. \% as the main constituent of the scales. The amount of other elements present in the powders are not significant as alloying elements. 
$\mathrm{Si}$, a common deoxidizer in steels and irons making [18], is detected at 1.811 ar. $\%$ or $0.601 \mathrm{wt} . \%, \mathrm{Mg}$ is at third by atomic fraction that is accounted for 0.768 ar. $\%$. Whereas, by weight, $\mathrm{Mn}$ is at third at 0.394 wt. \%. Carbon as the common constituent of steels and irons [18], as well as other light elements are under the limitation of the XRF detections. Since XRF is incapable to shed some light of crystal arrangement of a sample, therefore XRD characterization is required to determine the constituent phase of the mill scale.

Figure 1 shows peaks identification of the powders through different stages of the synthesis process as measured by XRD. The peaks were compared to the crystallographic models of for $\mathrm{Cu}-\mathrm{k} \alpha \mathrm{X}$-ray source from the experiments by Jette and Fotte [19] for $\mathrm{FeO}$ (wustite), Bragg [20] for $\mathrm{Fe}_{3} \mathrm{O}_{4}$ (magnetite) Rozenberg et al. [21] for $\mathrm{Fe}_{2} \mathrm{O}_{3}$ (hematite), and Kremenovic et al. [22] for $\mathrm{NiFe}_{2} \mathrm{O}_{4}$. Using Rietveld refinement, the estimation of mole phase fraction is presented in Table 2. Figure 1.a) indicates that the crystal structure predominantly belongs to $\mathrm{FeO}$ (labelled as a) with higher intensity at $2 \theta$ of $43^{\circ}$ compared to spherical crystallites. This suggests a strong preferred orientation of (200) and underdeveloped (111) at $2 \theta$ of $35^{\circ}$. This most likely is correlated with the hot strip mill process where force was applied during the formation of elongated steel bars, allowing a particular direction for crystal growth during the oxidation process. Low intensity peaks of $\mathrm{Fe}_{3} \mathrm{O}_{4}$ (labelled as b) were also observed, implying that further oxidation of the wustite took places. Rietveld refinement estimated that the $\mathrm{FeO}$ content is 97.9 mole. \% whereas the $\mathrm{Fe}_{3} \mathrm{O}_{4}$ content is 2.1 mole. \%

The oxidation of the mill scale took place during the hot milling process is determined as (1).

$$
2 \mathrm{Fe}+\mathrm{O}_{2} \rightarrow 2 \mathrm{FeO}
$$

This reaction generated $\mathrm{Fe}^{2+}$ ions, and further oxidation took places as (2).

$$
6 \mathrm{FeO}+\mathrm{O}_{2} \rightarrow 2 \mathrm{Fe}_{3} \mathrm{O}_{4}
$$

During this reaction, two ions out of the three $\mathrm{Fe}^{2+}$ ions were oxidized into $\mathrm{Fe}^{3+}$. These reactions occurred during the steel-shaping process, whereas the milling process conducted in this study is to break down the chunks of the mill to prepare it for the roasting process.

Figure 1.b) shows the XRD pattern after the roasting process at $600{ }^{\circ} \mathrm{C}$, the majority of peaks were identified with $\mathrm{Fe}_{2} \mathrm{O}_{3}$ (labelled as c), accompanied with relatively lower intensity magnetites $\mathrm{Fe}_{3} \mathrm{O}_{4}$ (b). In the previous study [4], there were no significant amount of $\mathrm{Fe}_{3} \mathrm{O}_{4}$ (labelled as b) observed. This probably due to the inconsistency of the oxidation during the hot milling process. Rietveld refinement estimated that the mole fraction of the $\mathrm{Fe}_{2} \mathrm{O}_{3}$ is 90.1 mole \% and 9.9 mole \% for $\mathrm{Fe}_{3} \mathrm{O}_{4}$. During the roasting process, the reaction of the oxidation process was as (3).

$$
2 \mathrm{Fe}_{3} \mathrm{O}_{4}+\mathrm{O}_{2} \rightarrow 3 \mathrm{Fe}_{2} \mathrm{O}_{3}
$$

During this reaction, the remaining of $\mathrm{Fe}^{2+}$ ions were oxidized into $\mathrm{Fe}^{3+}$, however, in this study, this reaction was not fully completed that some of $\mathrm{Fe}_{3} \mathrm{O}_{4}$ (labelled as b) was still present after the roasting process. Figure 1.c) displays the final samples after the mixing with $\mathrm{NiO}$ and two steps firing process. From the XRD pattern, there are no other peaks observed, hence the formation of the $\mathrm{NiFe}_{2} \mathrm{O}_{4}$ phases were fully completed. The reaction of the formation of $\mathrm{NiFe}_{2} \mathrm{O}_{4}$ was allowed by the diffusion of its constituent ions at elevated temperature and formulated as (4).

TABLE 1

ELEMENTAL COMPOSITION OF RAW MILL SCALE AS MEASURED BY XRF

\begin{tabular}{|l|l|l|l|l|l|l|l|l|l|}
\hline & \multicolumn{10}{|c|}{ Elements } \\
\hline & $\mathbf{F e}$ & $\mathbf{S i}$ & $\mathbf{M g}$ & $\mathbf{K}$ & $\mathbf{C a}$ & $\mathbf{T i}$ & $\mathbf{C r}$ & $\mathbf{M n}$ & $\mathbf{N i}$ \\
\hline $\begin{array}{l}\text { Wt. } \\
\%\end{array}$ & 98.053 & 0.601 & 0.338 & 0.205 & 0.137 & 0.004 & 0.126 & 0.394 & 0.134 \\
\hline $\begin{array}{l}\text { Ar. } \\
\%\end{array}$ & 96.913 & 1.181 & 0.767 & 0.289 & 0.189 & 0.004 & 0.134 & 0.396 & 0.126 \\
\hline
\end{tabular}

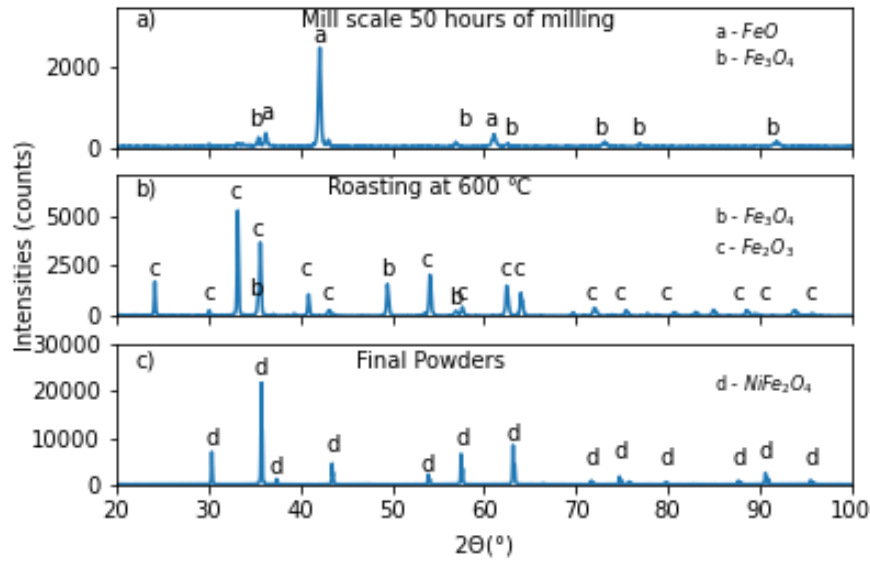

Figure. 1. a) Mill Scale after $50 \mathrm{~h}$ Ball Milling b) Resulted Powder after Roasting at $600{ }^{\circ} \mathrm{C}$ for $4 \mathrm{~h}$ c) Final Product after Sintering. 
TABLE 2

Phase QuANTIFICATION Estimated USING RiETVELd REFINEMENT FROM XRD PATTERNS

\begin{tabular}{|l|l|l|l|l|}
\hline \multirow{2}{*}{ Sample } & \multicolumn{4}{|l|}{ Phase fractions (mole. \%) } \\
\cline { 2 - 5 } & $\mathbf{F e O}$ & $\mathbf{F e}_{3} \mathbf{O}_{4}$ & $\mathbf{F e}_{2} \mathbf{O}_{3}$ & $\mathbf{N i F e}_{2} \mathbf{O}_{4}$ \\
\hline Mill scale & 97.9 & 2.1 & - & - \\
\hline $\begin{array}{l}\text { Roasted } \\
\text { Mill scale }\end{array}$ & - & 9.9 & 90.1 & - \\
\hline $\mathrm{NiFe}_{2} \mathrm{O}_{4}$ & - & - & - & 100 \\
\hline
\end{tabular}

$$
\mathrm{Fe}_{2} \mathrm{O}_{3}+\mathrm{NiO} \rightarrow \mathrm{NiFe}_{2} \mathrm{O}_{4}
$$

Figure 2 shows the Rietveld refinement of the final products. The XRD pattern was matched with the crystal structure of cubic $F d-3 m$ with lattice parameters provided at Table 3 . It suggests strong preferred orientation of (311). The lattice constant derived for the Rietveld refinement do not differ significantly from the past studies, $0.8322 \mathrm{~nm}$ in this study, lower compared to $\mathrm{NiFe}_{2} \mathrm{O}_{4}$ prepared using the chemical grade raw materials as reported by Zabotto et al. [23]. Unlike the small difference in the lattice constant, the unit cell density greatly differs from past studies. This can be explained by site occupancies refined by Rietveld refinement, which shows the ratio of $\mathrm{Ni}: \mathrm{Fe}: \mathrm{O}$ as $0.58811: 1.07695: 2.41826(0.97: 1.78: 4)$ compared to its chemical formula of $1: 2: 4$, thus the decrease in the unit cell density. The deviation from the standard formula may occur due to the presence of other elements, either alloying elements or impurities within the steels that underwent the hot strip mill process. Interestingly, the lattice constant does not change significantly, so that is highly possible that the impurities were fit well into the lattice thus maintaining the size of the lattice.

Figure 3 shows the formation of the Ni-ferrites after the sintering at $1260{ }^{\circ} \mathrm{C}$ for $3 \mathrm{~h}$. It can be seen that the particle sizes are quite heterogeneous, from the smaller particles as presented is $1.220 \mu \mathrm{m}$ and a large particle of $7.715 \mu \mathrm{m}$ also presents in the sample. The range is slightly lower and considerably wider compared to

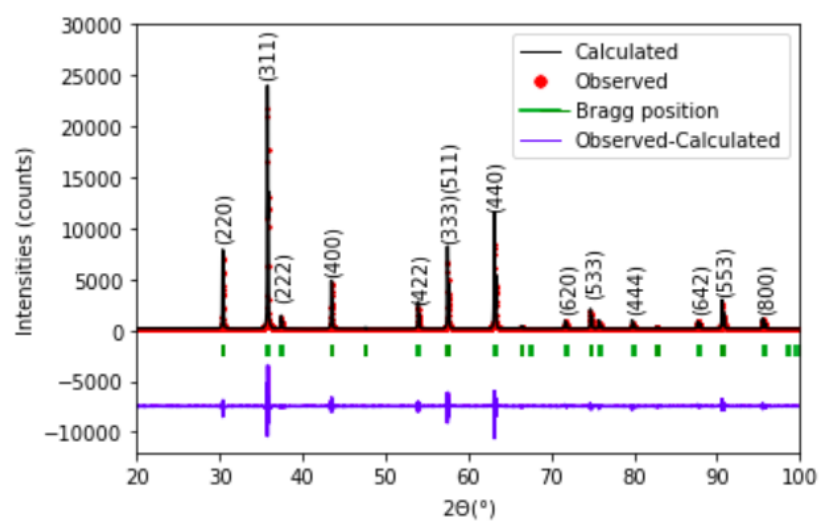

Figure 2. Plot of Rietveld Refinement of The Final Powders. The Initial Crystal Model were Obtained from [22].

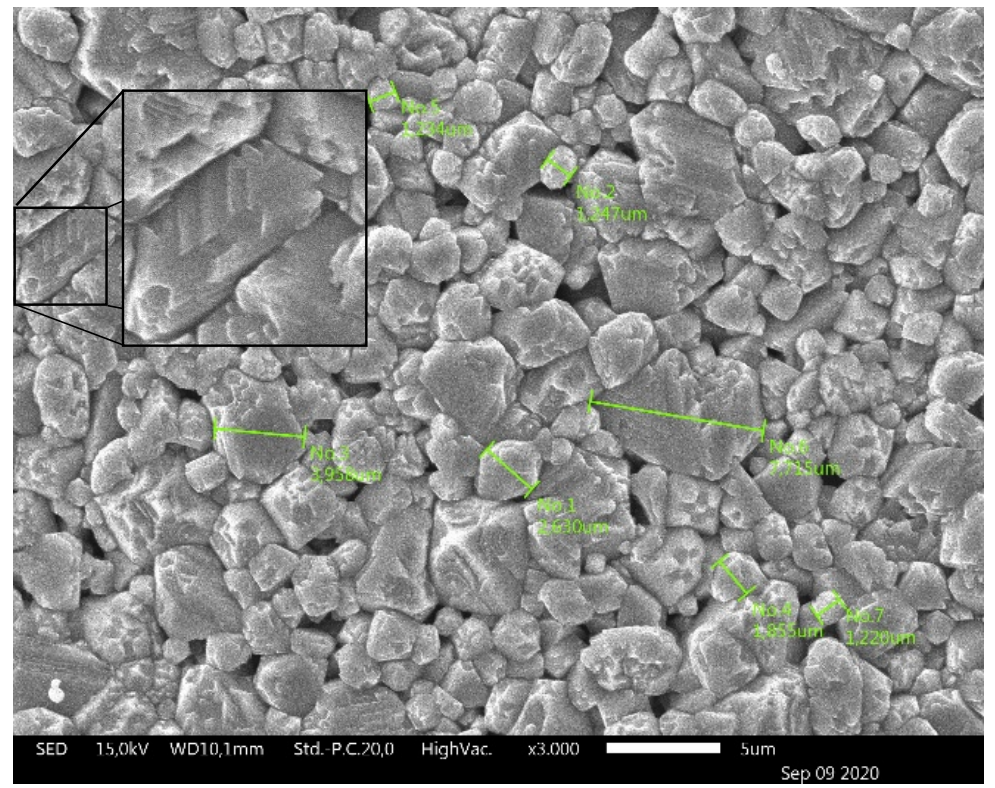

Figure 3. A SEM Image of 3000x Magnification of Ni-ferrites Prepared Using Oxidized Mill Scale. The Inset Shows Stacked Triangular Features That are often Observed in Spinel Ferrites. The Green Markers Reveal that The Range of The Particle Size is Relatively Wide. 
NiZn-ferrites prepared using mill scales as reported by Hari et al. [6], where the particle size observed from SEM images ranging from 4.578 to $8.69 \mu \mathrm{m}$. From the SEM image, we can see that there are voids in between the particles, this also confirmed with the density as measured using Archimedes method, as presented in Table 4, that shows $4.690 \mathrm{~g} / \mathrm{cm}^{3}$ or $92.3 \%$ density compared to the maximum theoretical density obtained by the Rietveld refinement at $5.084 \mathrm{~g} / \mathrm{cm}^{3}$. The density of the specimens compacted at $8.4 \mathrm{ton} / \mathrm{cm}^{2}$ increase significantly to 5.9 ton $/ \mathrm{cm}^{2}$, from $4.579 \mathrm{gr} / \mathrm{cm}^{3}$ to 4.974 $\mathrm{gr} / \mathrm{cm}^{3}$, however the density fell to $4.690 \mathrm{gr} / \mathrm{cm}^{3}$ when compacted at 10.9 ton $/ \mathrm{cm}^{2}$. This shows that the pressure of $10.9 \mathrm{ton} / \mathrm{cm}^{2}$ is excessive for the Ni-ferrites powders and it may accumulate excessive stress that induce cracks and defects that inhibit further densification. The inset in Figure 3 shows interesting feature of stacked triangles that are also found in other spinel ferrites such as CoMn-ferrites [24]. The elongated feature accords to the strong preferential of the (311) as indicated from the Rietveld refinement. The average crystallite size refined from the XRD pattern $(0.863 \mu \mathrm{m})$ gives smaller value than the particle size observed from SEM image.

Table 4 presents the quantification of the elements found in the final sample as measured by EDS. Other than $\mathrm{Ni}, \mathrm{Fe}, \mathrm{O}$ elements, there are other elements present such as $\mathrm{C}, \mathrm{Al}$, and small amounts of $\mathrm{Ca}$. From the elemental ratios at $1000 \mathrm{x}$ magnification, the ratio of $\mathrm{Ni}: \mathrm{Fe}: \mathrm{O}$ is $9.56: 24.3: 51.2$ (or $0.75: 1.89: 4$ ), where the ratio provided from the $3000 \mathrm{x}$ data do not greatly differ at $9.32: 23.74: 51.77$ (or $(0.72: 1.83: 4$ ). Compared to the site occupancies obtained from the Rietveld refinement $(0.97: 1.78: 4)$, Ni atoms yield lower amounts whereas Fe atoms yield higher ratio. In addition, both of the Rietveld refinement of XRD pattern and EDS data indicate that the $\mathrm{Ni}$ and $\mathrm{Fe}$ atoms present are lower than the standard formula of $\mathrm{Ni}: \mathrm{Fe}$ : $\mathrm{O}$ at $1: 2: 4$. This accords the lower density of the unit cell.

$\mathrm{C}$ is a well-known constituent of steels but partly is also coming from the glue of the holder of the SEM. A considerable amount of $\mathrm{Al}$, which has the stable ion form of $\mathrm{Al}^{3+}$. The single phase detected by XRD indicates that $\mathrm{Al}^{3+}$ are able to fit into the lattice and substitute $\mathrm{Fe}^{3+}$ since there are no other phases peaks detected. The substitution of $\mathrm{Fe}^{3+}$ by $\mathrm{Al}^{3+}$ was also observed in another spinel system $\mathrm{ZnFe}_{2} \mathrm{O}_{4}$ as a study conducted by Toledo et al. [25]. There are no other impurities or secondary elements detected other than the common elements within steel such as $\mathrm{Mn}, \mathrm{Si}, \mathrm{Cu}, \mathrm{Ni}$, $\mathrm{Cr}, \mathrm{Mo}, \mathrm{Al}[26]$.
Figure 4 displays the elemental mapping from the EDS detector for different elements. Figure 4.a) represents the SEM images of the surface stacked with the results of the mapping of the individual the elements. In Figure 4.e) and f), $\mathrm{Ni}$ and Fe atoms are well scattered across the particles, however there are some empty areas in Figure 4.b), c), and e), which contours follows the surface profile of the particles. $\mathrm{Ni}$ and $\mathrm{Fe}$ atoms have additional characteristic peaks at higher energy that have strong penetrative powers so it can go deeper under the surface. In Figure 5, it can be seen that $\mathrm{Al}, \mathrm{C}, \mathrm{O}$ has lower characteristic peaks whereas $\mathrm{Fe}$ and $\mathrm{Ni}$ has more characteristic peaks at higher energy (6 to 8 $\mathrm{keV}$ ). In addition, there are no clusters of $\mathrm{Al}$ atoms that is indicative that the $\mathrm{Al}$ atoms is fit well into the $\mathrm{NiFe}_{2} \mathrm{O}_{4}$ lattice, which is in good accordance with the result from Rietveld refinement.

Figure 6 displays the hysteresis of the samples after the sintering. It can be seen that the hysteresis curves are relatively invariant of the compaction pressure. This implies that the compaction pressure used in this study has little effect on the magnetization at low field of the $\mathrm{Ni}$-ferrites prepared using the oxidized mill scale. Table 5 displays the magnetic parameters derived from the Remacomp measurements. The coercivity values obtained from this study $(11.5$ to $11.7 \mathrm{Oe})$ have bigger values from the bulk $\mathrm{NiFe}_{2} \mathrm{O}_{4}$ prepared using the laboratory grade $\mathrm{Fe}_{2} \mathrm{O}_{3}$ sintered at $1200{ }^{\circ} \mathrm{C}$ as reported by Zabotto et al. [23] at a value of $0.4 \mathrm{kA} / \mathrm{m}$ or $5.02 \mathrm{Oe}$. The coercivity values are also higher than NiZn-ferrites prepared from mill scales [6] at 4.32 to 5.873 Oe. Coercivity translates to the magnetic field required to reverse the magnetization to zero, meaning that higher coercivity value, the magnetic properties becoming 'harder', i.e., it losses more energy per cycle of hysteresis.

TABLE 3

RIETVELD REFINEMENT PARAMETERS OF $\mathrm{NIFE}_{2} \mathrm{O}_{4}$ PREPARED FROM MiLl SCALES

\begin{tabular}{|l|l|l|l|}
\hline \multicolumn{1}{|c|}{ Parameters } & $\begin{array}{l}\text { This } \\
\text { study }\end{array}$ & $\begin{array}{l}\text { Kooti } \\
\text { and } \\
\text { Sedeh } \\
{[\mathbf{1 1}]}\end{array}$ & $\begin{array}{l}\text { Zabotto } \\
\text { et al. } \\
{[\mathbf{2 3}]}\end{array}$ \\
\hline $\begin{array}{l}\text { Lattice constant } \\
\mathrm{a}=\mathrm{b}=\mathrm{c}(\mathrm{nm})\end{array}$ & 0.8322 & 0.8321 & 0.834 \\
\hline $\begin{array}{l}\text { Unit cell volume } \\
\left(\mathrm{nm}^{3}\right)\end{array}$ & 0.5764 & 0.5761 & 0.580 \\
\hline $\begin{array}{l}\text { Unit cell density } \\
\left(\mathrm{g} / \mathrm{cm}^{3}\right)\end{array}$ & 5.084 & 5.405 & - \\
\hline Crystallite size (nm) & 863.3 & 48 & - \\
\hline Bragg R-factor & 5.74 & - & \\
\hline Goodness of Fit & 2.3 & - & \\
\hline
\end{tabular}

TABLE 4

EDS MEASUREMENTS FOR DiFFERENT AREA POINTS

\begin{tabular}{|c|c|c|c|c|c|c|}
\hline \multirow{2}{*}{ Elements } & \multicolumn{6}{|c|}{ Atomic ratio (at. \%) } \\
\hline & Area 1000x & Area 3000x & Point (1) & Point (2) & Point (3) & Point (4) \\
\hline $\mathrm{C}$ & 13.05 & 13.13 & 13.31 & 10.84 & 13.54 & 16.59 \\
\hline $\mathrm{O}$ & 51.2 & 51.77 & 43.85 & 41.77 & 44.52 & 38.02 \\
\hline $\mathrm{Al}$ & 1.86 & 1.97 & 2.35 & 2.5 & 2.3 & 2.38 \\
\hline $\mathrm{Fe}$ & 24.3 & 23.74 & 28.71 & 32.06 & 27.88 & 30.65 \\
\hline $\mathrm{Ni}$ & 9.56 & 9.32 & 11.79 & 12.83 & 11.75 & 12.36 \\
\hline $\mathrm{Ca}$ & - & 0.07 & - & - & - & - \\
\hline
\end{tabular}




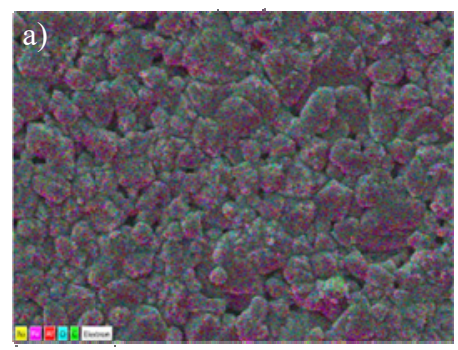

A KaI

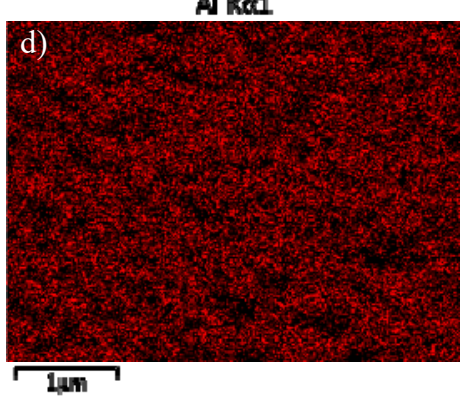

0 Ka1

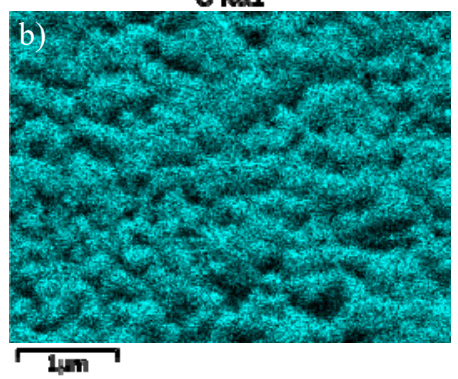

Fe Kal

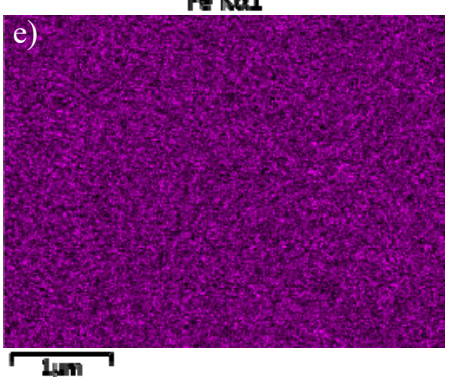

$\mathrm{C} \mathrm{Ka122}$

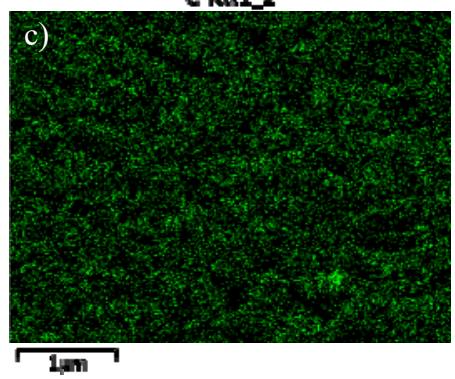

NII Kal

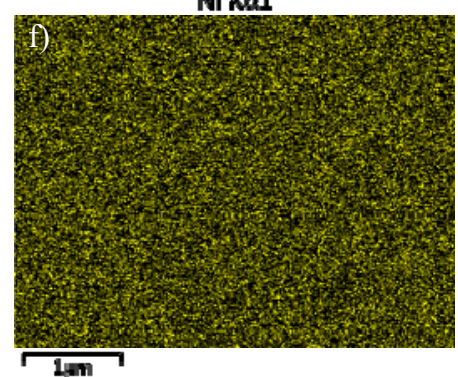

Figure 4. EDS Mapping of Ni-ferrites Prepared by Oxidized Mill Scale a) Shows All the Elements Mapping Present on Top of The Sample SEM Image b-f) Elemental Mapping of Oxygen, Carbon, Aluminium, Iron and Nickel Atoms, Respectively.

TABLE 5

MAGNETIC PARAMETERS FROM THE REMACOMP MEASUREMENT

\begin{tabular}{|l|l|l|l|l|}
\hline $\begin{array}{l}\text { Compacti- } \\
\text { on } \\
\mathbf{p r e s s u r e} \\
\left(\mathbf{t o n} / \mathbf{c m}^{\mathbf{2}}\right)\end{array}$ & $\begin{array}{l}\text { Density } \\
\left(\mathbf{g} / \mathbf{c m}^{\mathbf{3}}\right)\end{array}$ & $\begin{array}{l}\text { Remanence } \\
(\mathbf{e m u} / \mathbf{g})\end{array}$ & $\begin{array}{l}\text { Coercivity } \\
\mathbf{H c}(\mathbf{O e})\end{array}$ & $\begin{array}{l}\text { Magnetizati- } \\
\text { on at 4000 } \\
\mathbf{A} / \mathbf{m} \\
(\mathbf{e m u} / \mathbf{g})\end{array}$ \\
\hline 5.9 & 4.579 & 16.79 & 11.7 & 22.56 \\
\hline 8.4 & 4.974 & 16.87 & 11.7 & 22.31 \\
\hline 10.9 & 4.690 & 17.60 & 11.5 & 23.27 \\
\hline
\end{tabular}

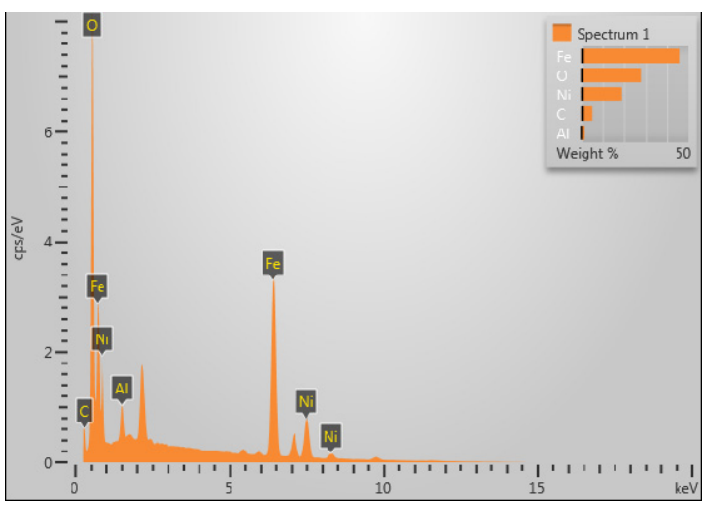

Figure 5. The EDS Spectra for 1000x Magnification

However, the coercivity is much lower compared to the study by Khedr [27] that used significantly lower compaction pressure that account for 276 to 365.5 Oe. Khedr has attempted to prepare Ni-ferrites using analytic grade starting materials and lower compaction pressure of 150,200 , and $250 \mathrm{~kg} / \mathrm{cm}^{2}$. Khedr has shown that the compaction pressure has significant effect on the magnetic properties. However, this is not the case with our study that the effect of compaction pressure is invariant to the magnetic properties. The compaction pressure used in our study are significantly higher, therefore, it is possible that within this range is close to the upper limit of the optimum compaction pressure. Thus, the effect of compaction pressure will have small effect on the magnetic properties.

The saturation magnetization values cannot be obtained using Remacomp since the maximum applied magnetic field is significantly low so it provides better resolution for soft magnetic properties. The remanence values are similar to the $\mathrm{NiFe}_{2} \mathrm{O}_{4}$ from the chemical grade raw materials at 17.44 to $18.95 \mathrm{emu} / \mathrm{g}$ as reported by Kooti and Sedeh [11]. However, from the structural studies, we estimate that the saturation magnetization may see a decrease due to the vacancies and the presence of $\mathrm{Al}^{3+}$ atoms in the lattice.

Figure 7 shows the S11 reflection loss of the samples and aluminium plate used during the measurement. The reflection loss patterns of the $\mathrm{NiFe}_{2} \mathrm{O}_{4}$ closely follow the aluminium plate up until 10 $\mathrm{GHz}$. At higher frequency, the absorption is still suspected coming from the contribution of the aluminum plate that is shifted to lower frequency. Zhao et al. [26] found that the reflection loss of $\mathrm{NiFe}_{2} \mathrm{O}_{4}$ nanosheets are thickness dependant at $8-12 \mathrm{GHz}$ rather than from the contribution of the ferromagnetic resonance since the permeability drops drastically in the $\mathrm{MHz}$ range [28]. 


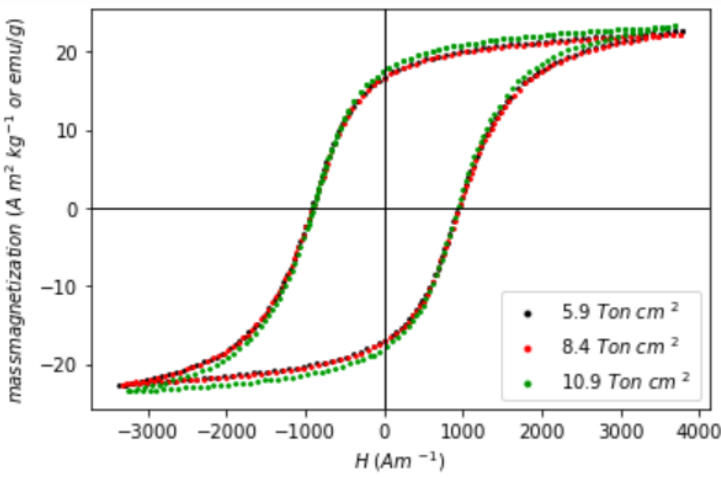

Figure 6. Magnetic Hysteresis of Different Compaction Pressure.

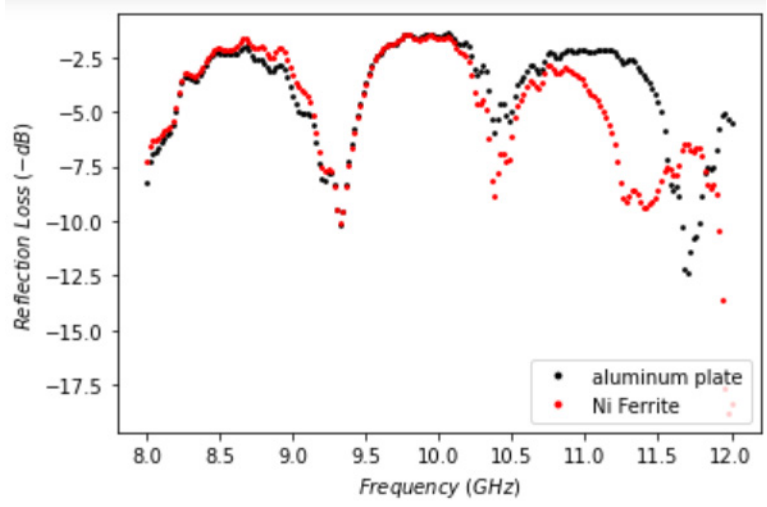

Figure 7. Reflection Loss (S11) of $\mathrm{NiFe}_{2} \mathrm{O}_{4}$ Prepared from Oxidized Mill Scales at $2 \mathrm{~mm}$ Thickness.

\section{CONCLUSION}

In this study, the preparation of $\mathrm{NiFe}_{2} \mathrm{O}_{4}$ from mill scales derived as by-product from steel making process using a facile solid-state reaction was successfully conducted. Single phase products of cubic Fd-3m $\mathrm{NiFe}_{2} \mathrm{O}_{4}$ were formed by its XRD pattern that was confirmed by Rietveld refinement. In addition, lattice defects such as vacancy of $\mathrm{Ni}$ and $\mathrm{Fe}$ atoms and partial substitution by $\mathrm{Al}$ atoms were detected, which were further confirmed by EDS measurement. Microstructure image reveals heterogeneous particle sizes and porosity was present in the sample. The coercivity of the $\mathrm{Ni}$ ferrites obtained in this study was higher than the Niferrites prepared using chemical grade raw materials. There were no significant reflection losses measured at $\mathrm{X}$-band region of 8-12 GHz.

\section{ACKNOWLEDGMENT}

This work was supported by Research Center for Electronics and Telecommunication, Indonesian Institute of Sciences (P2ET-LIPI). The authors acknowledge the facilities, and the scientific and technical assistance of the Center for the Utilization and Innovation of Science and Technology (PPII-LIPI) at the Indonesian Institute of Sciences. We acknowledge assist from Evridha Raevdha Nurmansyah and Della Sinthya Gita Ananda during the sample preparation process. We also thank Yaya Sulaeman for the discussion and the testing out the possibility of the application of dielectric resonator oscillator for specimens prepared in this study.

\section{REFERENCES}

[1] S. Cho and J. Lee, "Metal recovery from stainless steel mill scale by microwave heating," Metals. Mater. Int., vol. 14, no. 2, pp. 193-196, 2008.

[2] H. H. Hoffman and J. J. Hoffman, "Process for recovery of iron/steel from mill scales and fines," U.S. Patent US20150013497A1, Jan. 15, 2015.

[3] S. A. Abdel-Hameed, I. Hamed M., B. J. Muller-Borer, and N. A. Erhan, "Preparation and characterization of magnetic glass ceramics derived from iron oxides bearing rolling mill scales wastes," Nano Res. Appl., vol. 1, no. 1, pp. 1-11, 2015.

[4] A. Septiani, N. Idayanti, and T. Kristiantoro, "Preparation of barium hexaferrite powders using oxidized steel scales waste," in American Institute Physics Conf. Proc., vol. 1711, no. 1, 2016, pp. 020002-1-020002-4.

[5] Y. M. Z. Ahmed, E. M. M. Ewais, and Z. I. Zaki, "In situ synthesis of high density magnetic ferrite spinel $\left(\mathrm{MgFe}_{2} \mathrm{O}_{4}\right)$ compacts using a mixture of conventional raw materials and waste iron oxide," J. Alloys Compd., vol. 489, no. 1, pp. 269274, 2010.

[6] Z. Hari, M. W. H. Alias, A. Anuar, and N. A. Hamid, "A study of mill scale derived hematite process for NiZn ferrite as EMI suppressor in terms of magnetic properties," J. Eng. Appl. Sci., vol. 12, no. 17, pp. 4426-4430, 2017.

[7] C. E. Demirci, P. K. Manna, Y. Wroczynskyj, S. Aktürk, and J. van Lierop, "A comparison of the magnetism of cobalt-, manganese-, and nickel-ferrite nanoparticles," J. Phys. D: Appl. Phys., vol. 51, no. 2, pp. 1-11, 2017.

[8] M. A. Dar, J. Shah, W. A. Siddiqui, and R. K. Kotnala, "Study of structure and magnetic properties of $\mathrm{Ni}-\mathrm{Zn}$ ferrite nanoparticles synthesized via co-precipitation and reverse microemulsion technique," Appl. Nanosci., vol. 4, pp. 675-682, 2014.

[9] A. Franco and M. S. Silva, "High temperature magnetic properties of magnesium ferrite nanoparticles," J. Appl. Phys. vol. 109, no. 7, pp. 07B505-1-07B505-3, 2011.

[10] O. Yalçın, "Ferromagnetic resonance," in Ferromagnetic Resonance - Theory and Applications, UK: O. Yalçın IntechOpen, 2013.

[11] M. Kooti and A. N. Sedeh, "Synthesis and characterization of $\mathrm{NiFe}_{2} \mathrm{O}_{4}$ magnetic nanoparticles by combustion method," $J$. Mater. Sci. Technol., vol. 29, no. 1, pp. 34-38, 2013.

[12] L. Andjelković, M. Šuljagić, M. Lakić, D. Jeremić, P. Vulić, and A. S. Nikolić, "A study of the structural and morphological properties of $\mathrm{Ni}$-ferrite, $\mathrm{Zn}$-ferrite and $\mathrm{Ni}-\mathrm{Zn}$-ferrites functionalized with starch," Ceram. Int., vol. 44, no. 12, pp. 14163-14168, 2018.

[13] Z. Zhang, Y. Liu, G. Yao, G. Zu, and Y. Hao, "Synthesis and characterization of $\mathrm{NiFe}_{2} \mathrm{O}_{4}$ nanoparticles via solid-state reaction," Int. J. Appl. Ceram. Technol., vol. 10, no. 1, pp. 142$149,2013$.

[14] S. Sagadevan, Z. Z. Chowdhury, and R. F. Rafique, "Preparation and characterization of nickel ferrite nanoparticles via coprecipitation method," Mat. Res., vol. 21, no. 2, pp. 1-5, 2018.

[15] M. M. Bućko and K. Haberko, "Hydrothermal synthesis of nickel ferrite powders, their properties and sintering," J. Eur. Ceram. Soc., vol. 27, no. 2-3, pp. 723-727, 2007.

[16] D. H. Chen and X. R. He, "Synthesis of nickel ferrite nanoparticles by sol-gel method," Mater. Res. Bull., vol. 36, no. 7-8, pp. 1369-1377, 2001

[17] J. Rodríguez-Carvajal, "Recent advances in magnetic structure determination by neutron powder diffraction," Physica B: Condens. Matter, vol. 192, no. 1-2, pp. 55-69, 1993.

[18] ASM Handbook, Volume 1: Properties and Selection: Irons, Steels, and High-Performance Alloys, ASM International, Materials Park, OH, 1990.

[19] E. R. Jette and F. Foote, "An X-ray study of the Wüstite (FeO) solid solutions," J. Chem. Phys., vol. 1, pp. 29-36, 1933.

[20] W. H. Bragg, "The structure of magnetite and the spinels," Nature, vol. 95, p. 561, July, 1915.

[21] G. Kh. Rozenberg, L. S. Dubrovinsky, T. Le Bihan, M. P. Pasternak, O. Naaman, and R. Ahuja, "High-pressure structural studies of hematite $\mathrm{Fe}_{2} \mathrm{O}_{3}$," Phys. Rev. B, vol. 65, pp. 064112-1064112-8, 2002. 
[22] A. Kremenović, B. Antić, M. Vučinić-Vasić, P. Colomban, Č. Jovalekić, N. Bibić, V. Kahlenberg, and M. Leoni, "Temperature-induced structure and microstructure evolution of nanostructured $\mathrm{Ni}_{0.9} \mathrm{Zn}_{0.1} \mathrm{O}$," J. Appl. Cryst., vol. 43, no. 4, pp. 699-709, 2010.

[23] F. L. Zabotto, A. J. Gualdi, J. A. Eiras, A. J. A. de Oliveira, and D. Garcia, "Influence of the sintering temperature on the magnetic and electric properties of $\mathrm{NiFe}_{2} \mathrm{O}_{4}$ ferrites," Mat. Res., vol. 15, no. 3, pp. 428-443, 2012.

[24] V. Corral-Flores, D. Bueno-Baqués, A. V. Glushchenko, R. F. Ziolo, J. A. Matutes-Aquino, R. Sato-Turtelli, and R. Grössinger, "Magnetic properties of spinel cobalt-manganese ferrites," IEEE Trans. Magn., vol. 51, no. 4, pp. 1-6, Apr. 2015.

[25] J. A. Toledo, M. A. Valenzuela, P. Bosch, H. Armendáriz, A. Montoya, N. Nava, and A. Vázquez, "Effect of $\mathrm{AI}^{3+}$ introduction into hydrothermally prepared $\mathrm{ZnFe}_{2} \mathrm{O}_{4}$," App. Catal. A: Gen. vol. 198, no. 1-2, pp. 235-245, 2000.

[26] C. Zhao, W. Huang, X. Liu, S. W. Or, and C. Cui, "Microwave absorbing properties of $\mathrm{NiFe}_{2} \mathrm{O}_{4}$ nanosheets synthesized via a simple surfactant-assisted solution route," Mat. Res., vol. 19, no. 5, pp. 1149-1154, 2016

[27] M. H. Khedr, "Effect of firing temperature and compacting pressure on the magnetic and electrical properties of nickelferrite," Physicochem. Probl. Miner. Process., vol. 38, no. 1, pp. 311-320, 2004

[28] M. M. Pande, M. Guo, X. Guo, D. Geysen, S. Devisscher, B. Blanpain, and P. Wollants, "Impurities in commercial ferroalloys and its Influence on the steel cleanliness," in Proc. $12^{\text {th }}$ Int. Ferroalloys Congr. Sustainable Future, 2010, pp. 935-944. 